THE COLOURING MATTER OF THE TESTA OF THE SEED OF RAPE (BRASSICA NAPUS).

$T H E$ testa of the seed of this species of Brassica is dark brown in colour, so dark often as to appear almost black. Being curious as to the chemical nature of the colour in this outer seed skin, I made several very simple experiments (which, however, have been thoroughly successful) with a view to elucidate the matter. After trying many solvents I was able to dissolve out the greater part of the colouring material by the use of that very common solvent, viz. a 25 per cent. solution of hydrochloric acid.

I put two or three hundreds of rape-seeds into a large test-tube (boiling-tube), covered them over completely with the dilute hydrochloric acid, and let the whole stand for three days. ${ }^{1}$

At the end of that time the solvent had acquired a very distinct pale brownish-violet (inclining to magenta) colour.

When a little of this dilute hydrochloric acid extract was mixed with as much strong pure hydrochloric acid, and gently heated, an intense yellow colour was developed, pointing to the very probable presence in the solution of iron in the ferric condition.

When potassium ferrocyanide was added to another portion, in a test-tube, of the original dilute $\mathrm{HCl}$ solution, a pale greenish-blue colour, which gradually darkened, was produced, and, after standing for about a day, the characteristic Prussian-blue precipitate indicative of ferric iron was observed to have settled to the bottom of the tube.

Potassium sulphocyanide confirmed the results obtained above, by giving, when added to the original solution, a well-marked blood-red coloration, showing the certain presence of a ferric compound in the liquid tested.

By these simple experiments I proved the presence of iron. I now wished to ascertain the nature of the iron compound in the testa which gave it its characteristic colour. I adopted the following simple method of investigation :-

I soaked for about a day a hundred or so of seeds. Then I took off the s'sins, which the soaking had rendered easily removable, placed them on a clean platinum foil, and heated to and kept at a white heat till all the water and organic matters were driven off, and nothing but ash remained. This ash--which was very small in quantity, of course--was reddish-brown in colour, and so was undoubtedly, in large measure at least, ferric oxide. When this red ash was treated with moderately strong hydrochloric acid, the intense yellow colour due to the

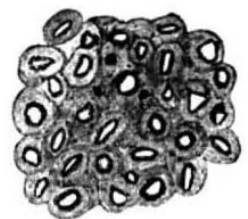

S:ction of testa of rape-seed showing thick corky cell-walls impregnatad with hydrated (?) ferric oxide. $(\times 160)$.

production of ferric chloride was developed, and the potassium ferrocyanide and the sulphocyanide give the characteristic tests recorded above.

No doubt, then, was left in my mind by these experiments that the iron existed in the state of ferric oxide (most probably hydrated ferric oxide or limonite) in the testa of the rape-seed. I was next anxious to know how the ferric oxide was distributed in the corky tissue of the testa. It soon occurred to me that this was also a very

${ }^{2}$ I know now that it was not necessary to let the seeds remain in the acid so long. By a little gentle and judicious heating for about twenty minutes sufficient of the colouring substance would be extracted to enable one to determine its nature. simple matter to investigate. I embedded several testas in paraffin, and by means of my microtome cut several thin sections, mounted in water, and examined them with a medium microscopic power. The cell-cavities were entirely empty; the thick corky walls were quite red. There, then, in the walls, plainly enough, the ferric oxide was seen to be distributed.

How did the ferric oxide get into its place in these walls? This, I think, is the explanation. The iron was taken in from the soil, by the root hairs of the plant which produced the seeds, chiefly in the ferrous state, probably as ferrous carbonate or chloride. It was conveyed in the water stream through the parent plant to the seed, and there deposited as an accessory substance in the cell-walls of the testa amongst the corky matter while the process of wall-thickening was going on. It was afterwards, or during the process of deposition, oxidized and hydrated (?), and so the seed of Brassica Napus acquired its characteristic tough dark brown testa.

Edinburgh University.

Alexander Johnstone.

\section{THE TAIL-BRISTLES OF A WEST INDIAN EARTHWORM.}

I HAVE recently received from Mr. Reginald Windle a small collection of earthworms from Bermuda, among which is a new species showing a remarkable peculiarity of structure which I have not observed, or seen recorded, in any other earthworm.

The posterior extremity, for the length of about half an inch (the worm measures about three inches), is furnished with bristles, which, as in Urochata, are disposed in an alternate fashion; the eight bristles on each segment do not correspond in position to those of the preceding or succeeding segments, but are placed so as to correspond to the intervals between them.

In my specimen the bristles at the end of the body were extremely conspicuous, and, when examined by a lens, appeared to end in a thickened head; the skin felt sticky when touched by the finger. When a portion of the body-wall was teased up in glycerine, and examined with a microscope, the bristles showed the very remarkable shape indicated in the accompanying woodcut (Fis. $\mathrm{I}, a)$. The bristle is very large-compared with those upon the more anterior segments $\cdot(b)$ and those of other

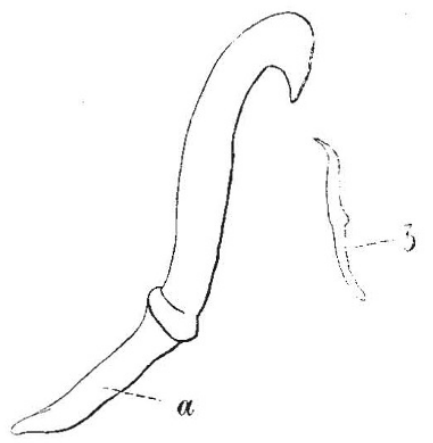

Fig. I. $-a$, one of posterior satæ; $b$, seta f:s n absut mid lle of body. Both drawn to scale with camera licida.

earthworms - and the free end is bent into a hook, the point of which lies in a direction nearly parallel to that of the shaft. The whole bristle is enormously thicker than those which are found upon the anterior segments, and of a deep yellow colour. At about the middle of the shaft, where a slight swelling is commonly met with in the bristles of other earthworms, is a thickened rim which suggests the attachment of powerful muscles. The hooked end of the bristles accounts for the "sticky" feeling of 